and the current haphazard uncoordinated development of community care will continue.

The proposals for care of mentally ill people are clearly an afterthought, a rapidly created and clever solution to the problem that local authorities have been reluctant to take on their responsibilities to care for mentally ill people. $\mathrm{Mr}$ Freeman outlined further plans to parliament the day after Mr Clarke's speech. The responsibility for assessing and organising care will be with local authorities, as for other care groups, but health authorities will control the grant and care plans will need to be approved before patients leave hospital. This should go some way to satisfying the psychiatric lobby pressing for health authority control.

The most welcome part of Mr Freeman's speech was the clear commitment to continue with the policy of closure of the large institutions but in a more controlled fashion. He has not bowed to the reactionary voices raised both in parliament and by some campaigners who wished to reverse the policy on the basis of a misguided idea that this would remove the problem of homeless, drifting, mentally disordered people. The disasters of the past 20 years of unplanned discharges cannot be reversed by bolting the stable door now. Especially welcome are the plans to allow unconventional private capital investment in hospital closure programmes, which will enable the right kinds of alternative accommodation to be developed as part of a package. The source of the revenue for double running costs incurred in a closure programme during the run down of a hospital is still not clear.

This is a partial response that could be fleshed out into a workable comprehensive policy. It largely addresses the problems of residential care. So far the government has ensured that it can contain spending on social security, and the Treasury must be well pleased. Now we want to see the details that will produce a well managed, properly coordinated community service, and we want to see such a service adequately funded. There is a great deal more work to be done before we can be enthusiastic about the proposals.

ELAINE MURPHY

District General Manager,

Lewisham and North Southwark Health Authority,

Guy's Hospital,

London SE1

1 Griffiths R. Community care. Agenda for action. London: HMSO, 1988.

\section{A European perspective in regulating clinical research}

\section{Britain needs a national ethical committee}

In the final analysis clinical research has to be self regulating if it is to be properly regulated. Codes, guidelines, committee review, and legal control will not produce a maximum of well conducted research unless they function to stimulate ethically informed behaviour that can be expected from the researchers themselves. Yet it is essential that research proposals are seen to be checked against agreed ethical standards and vetted by those who are not putting forward the proposals. A system of regulation beyond the judgment and conscience of individual researchers is essential if minimum standards are to be maintained in the face of the inexperience, haste, or poor judgment of the few who have brought clinical research into disrepute.

The survey by the Institute of Medical Ethics of the constitution and workings of hospital ethics committees in Britain ${ }^{1}$ and exposures of research malpractice in the $1980 \mathrm{~s}^{23}$ show that our system of public regulation leaves much to be desired. It cannot ensure public confidence in the ethical conduct of research when some of our committees do not insist on the need for our informed consent before all research procedures and are aware of research being undertaken that has not been ethically reviewed. We should not tolerate the vagaries that result from the Department of Health merely requesting health authorities to set up such committees and to adopt model constitutions drawn up by professional bodies. These vagaries culminate in the department being unable to say how many such committees exist, how they are constituted, and where they are located.

A meeting of representatives of European medical research councils in WHO regional offices in Europe earlier this year reinforced these points by showing how much may be learnt from the best European practices (particularly those in Scandinavia) without falling into the step of excessive, minute regulation set by the regulations of the National Institutes of Health in the United States. ${ }^{+}$

Four things are needed. Firstly, ethics committees need official status and recognition when they are set up. Secondly, they need a uniform, core constitution backed by government regulation and guaranteeing active lay participation in their deliberations. Thirdly, they need an optimal workload to encourage experience of ethical review to be built up within them. Fourthly, some kind of national ethics committee is needed to function not so much as a court of appeal in individual proposals but more as the source of guidance on general principles and of some measure of uniformity of practice in relation to particularly contentious decisions.

A national committee for research ethics could in Britain be combined with a national body for guidance on medical ethics in general (as is the case in France). Its potential usefulness is shown when we consider the following questions: How are local committees to decide on the principle (maintained by some) that randomised trials do not require full informed consent from patients enrolled into cohorts receiving standard treatment in a comprehensive study? Are we to tolerate randomised controlled trials being treated as a justified exception to the consent rule in one part of the country but not in another? If we need a central body to oversee and report on the ethics committee in clinics for in vitro fertilisation why do we not need one for establishments conducting research outside embryology?

Above all we need an exchange of ideas and the harmonising of practices among European nations. These are demanded by the international nature of much research, the possibility of contentious research projects being carried out in places where control is most lax, and the fundamental need to learn from each other's successes and failures.

PETER BYRNE

Lecturer in Philosophy of Religion,

Centre of Medical Law and Ethics,

King's College,

London WC2R 2LS

1 Nicholson RH, ed. Medical research with children. Oxford: Oxford University Press, 1986.

2 Faulder C. Whose body is it? London: Virago, 1985.

3 Byrne P. Medical research and the human subject: problems of consent and control in the UK experience. Ann N Y'Acad Sci 1988;530:144-53.

4 Levine RJ. Ethics and the regulation of clinical research. 2nd ed. Baltimore and Munich: Urban and Schwarzenburg, 1986. 